This is the author's version of a work that was submitted to / accepted for publication.

To cite this chapter:

Hemming, P. J. 2016. Childhood, youth, and religious identity: mapping the terrain. In: Worth, N., Dwyer, C. and Skelton, T. eds. Identities and Subjectivities. Geographies of Children and Young People Vol. 4. Springer, pp. 1-18., (10.1007/978-981-4585-91-0_2-1)

\title{
Childhood, Youth and Religious Identity: Mapping the Terrain
}

Peter J. Hemming, HemmingPJ@cardiff.ac.uk, Cardiff University, School of Social Sciences

\begin{abstract}
This chapter outlines the broader interdisciplinary field of emerging academic work on childhood, youth and religious identity, identifying and investigating the geography than can be found within it. It begins by outlining the foundations of the field, before introducing the concept of religious identity and some of its key features. The chapter then goes on to explore a range of cross-cutting themes including socialisation, agency, expression and belonging. The role of geographical concepts and perspectives are considered in each of these four sections. The chapter ends with reflections on future directions and challenges for the study of religion and religious identity in geographies of children and young people.
\end{abstract}

\section{Introduction}

The study of religion in geography has seen substantial growth over the last couple of decades, a trend that has been reliably and competently documented by Lily Kong's (1990, 2001, 2010) decennial reviews in Progress in Human Geography. These reviews have mapped the development of the sub-discipline from a primary concern with religion's distribution, diffusion, demographics and dynamics, to an interest in the spatial politics and poetics of religion, and the significance of identity, community, post-secularism and diversity (of the religious, spatial, sensuous and demographic kind). In the most recent review, Kong (2010) highlights children and young people as one of the new population constituents gaining the attention of geographers of religion. She situates this within the more general development of the geographies of childhood and youth sub-discipline, evidenced in this current volume and book series.

This chapter seeks to go beyond Kong's (2010) review, by drawing on work from a range of disciplines to identify and investigate the geography that can be found within a broader field of emerging academic work on childhood, youth and religious identity. It begins by outlining the foundations of the field, before introducing the concept of religious identity and some of its key features. The chapter then goes on to explore a range of cross-cutting themes including socialisation, agency, expression, and belonging. The role of geographical concepts and perspectives are considered in each of these four sections. The chapter ends with reflections on future directions and challenges for the study of religion and religious identity in geographies of children and young people.

\section{Foundations of the Field}

Geographical scholarship on children and young people has drawn heavily on the 'new' social studies of childhood. This body of work acknowledges the socially constructed nature of childhood as a category and the way it has varied across time, space and cultures. Within this approach, children are viewed as a variable of analysis in their own right, rather than merely subsumed as part of a family or educational unit, and as social actors and agents who are 
actively engaged in constructing their own life worlds (James and Prout, 1997). Research has therefore tended to emphasise the child- and youth-centred study of children and young people, taking their own priorities and concerns as starting points for social enquiry. Consequently, ethnography has often proved a useful methodology for exploring children and young people's everyday lives, and uncovering depth and meaning in a way that other approaches cannot always achieve (James, 2001). This has sometimes involved the use of creative or "childcentred' methods, such as drawing, drama and photography, to provide diverse opportunities for children to communicate their perspectives (Barker and Weller, 2003).

Research on childhood, youth and religion, however, has not always followed a similar pathway. Earlier work on the subject relied quite heavily on Piagetian influenced psychological and developmental approaches to childhood, for example defining age groups and cognitive stages by which children were supposed to understand religious knowledge and identity (e.g. Goldman, 1964). Criticisms of such approaches include the fact that childhood 'development' is socially, culturally and historically specific, and that decontextualized laboratory experiments cannot accurately represent children's full capabilities. More recently, scholars in the field have questioned the marginal place of children and young people in their home disciplines, identifying a tendency to view these constituents as outside of mainstream concern (e.g. Bunge, 2006 on religious studies), or instead pointing to a failure to view the category of childhood through a more critical lens and to move away from adult-centred concerns such as pedagogy and philosophy (e.g. Miller-McLemore, 2006 on religious education).

Another strand of research in the field has approached the issue of childhood, youth and religion from a quantitative perspective. Many of these studies have employed surveys to investigate young people's religious attitudes and values (e.g. Kay and Francis, 1996, Ziebertz and Kay, 2006). This body of research benefits from a focus on young people's own answers and is helpful for identifying broad patterns and relationships, as well as important influences on religious identities and experiences. However, in an attempt to 'measure' religion, such approaches inevitably simplify a rather complex phenomenon, reducing it to objective markers and neat packages, rather than exploring real depth and nuance. Questionnaires are also notoriously difficult to use with younger children because of problems with comprehension, hence most of the work in this area focuses on teenagers and young people. Despite their strengths then, quantitative approaches may complement but on their own, can rarely constitute, a child- or youth-centred approach to the study of religion, due to difficulties in fully engaging with children's and young people's priorities and perspectives.

It would be wrong to suggest, however, that a 'child- and youth-centred' approach has always been missing from research on childhood, youth and religion. There have been a number of high quality ethnographic studies in the field of religious education stemming back to the early 1990s, most notably from scholars at the University of Warwick in the UK. For example, Nesbitt's (2004) work highlights key issues about children's religious beliefs, practices, traditions and celebrations from a range of different faith backgrounds and their relevance for religious education in the school context. More recent work in this area has engaged with questions about inter-faith relations and dialogue, following the wider social and educational policy interest in these issues (e.g. McKenna et al., 2008). Also informed by quantitative studies, such as those discussed above, this body of research has been important for developing new perspectives on curriculum and pedagogy in religious education (e.g. Jackson, 1997; 2004).

There is also a large body of research on children's spirituality, again mainly developed within the disciplines of education and religious education. Some of this work has operated within a religious framework (e.g. Coles, 1990; Heller, 1986), dealing with issues such as worship, prayer, and the divine. Others have focused on a broader understanding of spirituality, encompassing concepts such as 'experience', 'meaning', 'purpose' 'connection' and 'transcendence' or the non-rational and material aspects of existence (e.g. Hart, 2003; Hay and Nye, 1998). There are also examples of more holistic studies that bridge the religious and nonreligious divide (e.g. Erricker et al., 1997). This collection of work is significant firstly because it includes a focus on younger children, sometimes even of pre-school age, and secondly 
because it features the use of creative 'child-centred' methods, such as drawing and artwork. Together with the ethnographic studies mentioned in the previous paragraph, this body of research constitutes a much more 'child-centred' way of approaching the topic.

More recently, there has been a significant expansion of work on childhood, youth and religion, much of which is consistent with the 'new' social studies of childhood. One notable development has been in the disciplines of religious studies and theology, where constructions of childhood are beginning to be viewed in a much more critical light, and children's voices and experiences included more in theological discussions and debates (see Ridgely, 2012). In the past few years, there has also been a major growth in research on children, young people and religious identity, including a number of large-scale, mixed-method studies (mentioned later in the chapter). These developments have originated from a range of disciplines including religious education, sociology, psychology and of course human geography. As the field continues to grow, a number of key themes begin to emerge, all of which possess a geographical dimension. These themes are explored in detail later in the chapter but the complex concept of religious identity is first introduced.

\section{Religious Identity}

As will be apparent throughout this volume, identity has become a central concern for geographies of children and young people, in part as a reflection of its longstanding significance in social geography. The concept of identity is inherently geographical because it is contingent on space, place and social context. This is the case both for personal identity, which refers to an individual's distinctive biography and unique sense of self, as well as social identity, which relates to the wider social groups with whom the individual shares commonalities (Bradley, 1996). Social identity, including attributes such as gender, class, ethnicity, (dis)ability and sexuality, can influence a person's social location within society and how (s)he interacts with others. It not only relates to perceptions about who that individual is, but also who (s)he is not, hence constituting social differences in particular ways (Payne, 2000). Social identities play a key role in shaping and interacting with personal identities, hence contributing to individual biographies.

Identity is not constructed in a vacuum but may change and evolve through interaction with social actors, spaces and processes. Hall's (1992) 'sociological subject' draws attention to the relational nature of identity by eschewing the idea of an innate, autonomous human self. Instead, this model insists that identity is formed through interaction between the self and others, shaping a person through participation in social structures. Postmodern developments have also emphasised the multiple and contradictory nature of identity as a fluid project, resulting from the competing social interactions and diverse social contexts that individuals encounter in their everyday lives (Giddens, 1991). Social identities are thus subject to continual negotiation, and are performed across a range of social spaces and at different stages of the life-course. They are also structured through interaction with other social identities via complex processes of intersectionality (the interplay between social differences, often resulting in multiple forms of (dis)advantage). This is why identity is so intermeshed with space and place. It cannot be understood as fixed and ascribed, but rather fluid and socially and spatially contingent.

Religious identity can be viewed as a social difference alongside the likes of gender, social class and ethnicity. In a similar way to the aforementioned categories, religion often constitutes an axis of difference, structuring social interaction, influencing social location, and constructing social boundaries. The concept of religion itself is rather complex and multifaceted, consisting of different dimensions. For example, Lincoln (2006: 5-7) suggests a useful definition encompassing 'discourse', 'practice', 'community' and 'institution' in order to account for the variety of functions inherent in the term's meaning. However, there are also a range of other definitions, some of which place more emphasis on thought and belief (Weberian), and others on action and ritual (Durkheimian). Consequently, religious identity is also a complex concept 
and includes a number of components: affiliation and belonging, behaviour and practice, beliefs and values, and religious and spiritual experiences. This multidimensional nature of religious identity has long been recognised (e.g. Stark and Glock, 1968) and is integral to recent discussions about the nature of Christianity in contemporary European societies, such as whether or not individuals continue to hold religious beliefs despite eschewing religious institutions (e.g. Davie, 2007).

Intersectionality is an important concept for understanding religious identity. Existing research has pointed to the significance of other social identities and the ways in which they intersect with religion. Gender has often been a key focus because girls are generally understood to demonstrate higher levels of religiosity than boys, along with variations in religious

understandings, behaviours, attitudes and experiences (e.g. Levitt, 2003; Smith et al., 2003). Age has also been of interest to researchers, but findings have been less conclusive. Whilst some studies suggest that children and young people show declining levels of religiosity with age (e.g. Francis, 2001; Wallace et al., 2003), others maintain that age is not significant for influencing religious attitudes and behaviours (e.g. Mason et al., 2007; Smith et al., 2003). Class, sexuality and disability have generally received much less attention in the literature on childhood, youth and religious identity, despite their fact that are also significant markers of social difference (although see Ramji, 2007; Yip and Page, 2013). This may be a reflection of the emerging nature of the field and hence its lack of engagement with issues that have at different times been marginalised within social scientific research.

Ethnicity has a much closer and sometimes overlapping connection with religion, and studies concerned with this relationship have often focused on minority communities in Western societies (although exceptions include Day, 2011 as discussed later). Key themes in this literature include the different ways and contexts in which ethnic and/or religious labels are used (e.g. Baumann, 1996; Moinian, 2009), the relative significance of religious identities in comparison to ethnic, cultural and national ones (e.g. Duderija, 2007; Valentine and Sporton, 2009), and the role of religion in processes of racism and exclusion (e.g. Hopkins, 2004; Lewis, 2007). Religion may have the effect of setting up social boundaries, hence strengthening minority identities (e.g. Jacobson, 1998), and may even differentiate individuals from other groups that share ethnic and cultural traits (e.g. Raj, 2000). In its entirety, this body of work emphasises the complex, fluid and interconnected relationship between religious and ethnic identities.

The geographical nature of children and young people's religious identity is apparent firstly through the ways in which it takes shape variably within and across a range of social spaces and contexts. These include the home and family, the school, the peer group, faith and neighbourhood communities, media space and society as a whole (Hemming and Madge, 2012). However, there are also a number of other geographical dimensions present within this research field and these are now explored through a focus on the key themes of socialisation, agency, expression and belonging. As is inevitable in a contribution of this kind, the studies mentioned here are intended to provide an illustrative rather than exhaustive representation of the issues under consideration.

\section{Socialisation}

The maintenance of religion from one generation to the next is clearly a key concern for the field of research on childhood, youth and religious identity, and the family is an important arena in children's and young people's everyday lives. The concept of intergenerational religious transmission has often been used to refer to the process by which parents pass on their beliefs to their children, particularly at the scale of the population as a whole. Studies on religious transmission tend to be quantitative and large-scale in nature, often attempting to measure how successfully a particular group's religious affiliation and practice is relayed across generations and over time (Boyatzis et al., 2006). Yet the term 'transmission' tends to imply a rather simplistic and unidirectional process, with children and young people passively and 
automatically 'receiving' religion from their parents and families. The reality is, of course, much more complex and the terms 'socialisation' (the adoption of cultural norms and values) and 'nurture' (promoting growth and development) tend to capture the everyday micro-level realities of intergenerational religious processes much more successfully (Scourfield et al., 2013).

The concept of socialisation has often had rather a bad press within the 'new' social studies of childhood. It has generally been associated with developmental psychology, and the quite passive and linear constructions of childhood that have traditionally been prevalent within this school of thought (James et al., 1998). However, childhood theorists have recently sought to bring together developmental and social-cultural understandings of childhood and to break down unhelpful dualisms. As Honig (2009:67) argues, "if childhood studies have nothing to say about children growing up, they will have constituted with a disinterest in children's growing up". Socialisation can still be understood as a useful concept if approached from an interpretive perspective. The symbolic interactionist view of socialisation sees it as a process of interaction between children and adults, hence constructing the child as a social actor with a constitutive and self-reflexive role (Musolf, 1996). Socialisation can, therefore, be just as much about the everyday realities of being a child, than the pathway of development towards adulthood.

The complex processes involved in religious socialisation are illustrated well through a consideration of two key studies. The first is by Hopkins et al. (2011) and documents the dynamics of intergenerational religious relations of young Christians in Scotland (aged 16-27). In many ways this study is quite typical of work on children, young people and religion, in that it focuses on the upper end of the childhood and youth age spectrum, and considers the identities of white Christian young people. However, the study is distinctive in the way that it teases out the multiple and nuanced subject positions inherent in the intergenerational religious processes considered. Hopkins et al. (2011) categorise these positions as 'correspondence' (adopting similar, but not identical, positions to their parents), 'compliance' (conforming to parental religious expectations but privately questioning them), 'challenge' (openly debating and negotiating the religious position of family members), and 'conflict' (adopting combative stances that are in contradiction with those of their parents).

The second study is by Scourfield et al. (2013) and focuses on the religious nurture of Muslim children in Wales. This research does offer something quite different from the norm, in that its constituent group is children in 'middle childhood' (aged 4-12) and their families, and the study draws on a range of 'child-centred' methods. It also considers the experience of a minority religious group in a Western context, which may be subject to theories of 'minority defence'. As Scourfield et al. (2013) outline, most Muslims in the UK are visibly from an ethnic minority and many have experiences that fall outside of the mainstream population (e.g. of migration, social and economic disadvantage). As such, religion may be particularly significant in a situation where it may help to preserve a distinctive group culture or identity. Within this context, Scourfield et al. (2013) document the various forms of religious socialisation experienced by the children in their research, such as learning the correct way to pray and recite the Qur'an, as well as how to behave appropriately as a Muslim. These processes of socialisation took place through overt religious teaching in the home and supplementary schools (e.g. madrasahs), and more subtle influences from a range of other sources.

Taking the findings of these studies together, they highlight some significant points about the space of intergenerational socialisation itself. Rather than consisting of passive and unidirectional processes, this space is extremely dynamic, with active participation from both parents and children. For example, in the study by Hopkins et al. (2011), young people responded to their parents' religious nurture in a variety of ways, often contesting the notion that religious tradition is either wholly successfully or unsuccessfully transmitted. In contrast to this dominant model, young people demonstrated a variety of active subject positions in relation to their parents, including correspondence, compliance, challenge and conflict. There were also examples of participants influencing their parents' religious beliefs and practices, hence challenging the unidirectional model. Processes of negotiation were much more limited in the study by Scourfield et al. (2013), yet children nevertheless actively resisted religious teachings, 
albeit in small ways, for example through frequent trips to the toilet during Qur'an classes or mouthing Christian worship in school assemblies. Clearly there is an issue here about religious agency and the extent to which children had the opportunity to express this at different ages, but this will be explored further in the next section.

The spaces within which religious socialisation took place were also much more varied than traditional accounts of transmission allow for. In line with interpretive theories of socialisation that include both primary and secondary stages, children and young people not only received religious input from their parents, but also from their extended families (most notably grandparents), friends and religious leaders and teachers. The home was an important space of nurture for Muslim children to learn appropriate beliefs, practices and behaviours in Scourfield et al.'s (2013) research. This formal learning was reinforced more informally through material objects and symbols around the home such as Arabic texts, prayer mats, photographs of mosques, and copies of the Qur'an. However, religious identities were also shaped in formal supplementary classes, through multimedia and cyberspaces (via online tutors) and in more subtle ways in the wider community. Although the home was an important site for processes of religious socialisation in Hopkins et al.'s (2011) study, the authors identify a range of other significant spaces including schools and youth groups. They also suggest that religious discussions took place in a number of 'alternative sites of transmission', including journeys to and from church, and walks in the countryside.

\section{Agency}

The idea of children as social agents in their own right is central to the 'new' social studies of childhood but popular understandings of children rarely acknowledge their agency within the religious realm. The continuation of a religious tradition relies heavily on its successful transmission between the generations and hence too much agency on the part of children could be viewed by some as a threat to this. Even those arguing against the religious indoctrination of children tend to assume that they are passive recipients of religious teachings, rather than interpreting such messages actively and critically. Yet as was apparent in the previous section on socialisation, children and young people may often play quite an active role in the construction of their religious identities. This can stem from minor contestation of religious practices, as in the case of the children in Scourfield et al.'s (2013) study (see also the examples in the next section), or alternatively much more significant renegotiations of religious beliefs and identities, as with the young people in Hopkins et al.'s (2011) research.

It is important not to overstate the religious agency available to children and young people, although often the extent of their agency is influenced heavily by the age of the child. As mentioned previously, the discipline of childhood studies has recently shown a renewed interest in the concept of development, accepting that younger children cannot be expected to demonstrate the same capabilities or agency as older children, due to their lack of social experience if not biological development. As Scourfield et al. (2013) point out, it is not unusual for the lives of children in early and middle childhood to be significantly influenced by their parents and other adults, their religious agency thus expressed within tightly-set limits. In contrast, teenagers and young people are likely to experience much more freedom to develop their own religious positions and experiences. The young people in the study by Madge et al. (2014) agreed with this, describing how their views and ideas about religion had changed and evolved as they moved from middle childhood into adolescence and started to grapple with their developing identities in a wider sense. Whatever the age, however, it is likely that most children and young people have the ability to demonstrate some religious agency.

Hemming and Madge (2012) outline four ways in which previous literature has shown the potential of children and young people to express religious agency. The first is that children and young people may attach their own personal value and importance to particular religious and spiritual concepts, ideas and practices. These elements may sometimes be very different to those of adults, constituting a 'child-centred' experience of religion. The second is that children 
and young people may reconfigure and renegotiate formal religious meanings and practices. The complex processes of religious socialisation highlighted in the last section from Hopkins et al. (2011) and Scourfield et al. (2013) provide good examples of this. The third is that children and young people draw on a wide range of sources to make sense of religious issues and concerns, including their own faith, other religions, science, the media and their own experiences. They are certainly not religious 'dupes' passively accepting everything that adults tell them. The fourth way in which children and young people may demonstrate religious agency is most relevant to this chapter, in that they may develop their own complex religious identities that often challenge dominant representations and discourses. This is especially the case for minority religious groups, who sometimes experience stereotyping and discrimination from the wider society.

Dwyer's (1998; 1999) work on young British Muslim women is particularly useful for illustrating this fourth way of expressing religious agency, within the context of the diasporic community. The participants in her research, who were all of secondary school age, used a variety of strategies to negotiate their own religious identities, through the use of dress. The girls would resist the false dichotomy between 'traditional' and 'passive' Asian clothes and 'modern' and 'rebellious' Western clothes through mixing and matching. In this way, participants actively constructed their religious identities in opposition to dominant societal discourses. Similar strategies were employed to negotiate expectations from parents, classmates and the wider Muslim community. Islamic dress was one way in which the young women could assert their own identities, either by challenging cultural norms by 'covering up' through the use of nonconformist dress, or by wearing the hijab against parental wishes, reworking meanings of the headscarf as both a symbol of religious identity but also resistance. There was also a spatial dimension to these strategies, reflected in the way that the girls would wear different configurations of clothing at home, school and in public space. For example, some of the young women felt less comfortable wearing religious dress at school due to the perceptions of other pupils, but were more willing to challenge their parents' and community's expectations at home and in public space. Other girls used the school toilets as a space in which to experiment with make-up and different styles of headscarves, in a way that they would have felt less comfortable doing at home.

The concept of agency also has salience for making sense of young religious identities at a wider societal scale. Sociologists have pointed to the significance of individualisation, choice and consumption for both religion and self-identity in late modern societies. It should therefore come as no surprise that the construction of religious identity is also influenced by these aspects of post-modernity. Madge et al. (2014) found that many young people in their British study tended to emphasise personal choice, individualism and agency in their accounts of their own religious identity. This was even the case for those individuals the authors describe as 'strict adherents', who were keen to stress how it had been their own personal decision to remain devoutly committed to their faith. However, it was often clear from participants' responses to other questions that their agency nevertheless operated within various familial and community restraints. In other words, young people often invested heavily in the discourse of liberal individualism, foregrounding their own agency, even in cases where the reality of their religious lives did not always completely support these claims. This was no doubt a reflection of the particular societal context within which their identities were constructed, and the cultural value placed on individuality within this context. Both of the above examples work as a useful reminder of the complex nature of children's and young people's religious agency, and the importance of geography for the way it is understood and enacted.

\section{Expression}

Much of the research on young people and religion has been concerned with what might be termed the 'expression' of religion. One of the most obvious ways of thinking about this is through the lens of religious belief, something that has been considered by all of the most recent large-scale studies in this area (e.g. Madge et al., 2014; Mason et al., 2007; Smith and 
Denton, 2005; Ziebertz and Kay, 2006). The over-riding narrative from this research is that of diversity. As Madge et al. (2014: 208) put it, "by their teenage years [...], young people display a wide variety of faith positions and ways of expressing their religiosity, both across and within faith groups". Yet despite this, common threads regarding the changing nature of belief amongst young people in late modern societies do still appear within these studies. These include the increasing prevalence of individualised beliefs and understandings, the tendency to focus on happiness and interpersonal relationships rather than doctrinal truths, and the variable but nevertheless pertinent influence of secularisation on overall levels of belief and religiosity.

The religious beliefs of young people also have a geographical dimension. Clearly the studies discussed in the above paragraph all took place within Western contexts and are so likely to be influenced by the late modern nature of these societies. This is confirmed by Madge et al.'s (2014) analysis, which shows that religion was viewed as less important by young people and belief in God less certain, the more family members that had been born in the UK. In other words, recent immigrants were much more likely to express religiosity than those whose families were settled, a pattern that the authors refer to as a 'generation effect'. Madge et al. (2014) argue that this finding is evidence of the effects of Westernisation (with its secularising tendencies) but it also shows the influence that international migration and geographical mobility can have on the religious identity of families and their children. The significance of more smallscale mobility, specifically the experience of going to university, is explored in the next section.

Place is not only important at the national level, but also at a more local scale. Madge et al. (2014) describe what they refer to as a 'locality ethos', which seemed to influence religiosity and religious belief in each of the three research areas they focused on in England. In Newham, East London, they found there were greater numbers of young people who reported that religion was important in their lives, held a belief in God and expressed positive attitudes towards religion, than in Hillingdon in West London, or Bradford in West Yorkshire. In other words, there was something about each of the localities that seemed to influence levels of religiosity over and above the general variations characteristic of the different religious and ethnic groups present in the study. For example, religion was more likely to be viewed as 'very important' by White Christians living in Newham, than White Christians living in Hillingdon or Bradford. This is a very interesting finding that is worthy of further enquiry.

Religious expression is not just about belief however, as practice is also a key component of religious identity. Recent work has begun to question the distinction between the two, arguing that in a late modern context, it makes more sense to view believing as a practice or performance in itself rather than considered solely in the context of propositional belief systems (Day, 2011). This idea is extended by Vincett et al. (2012) in their research on young socially and economically included Christians in Scotland. They argue that these young people emphasise 'performance Christianity', through everyday religious action and practical expression. For these participants, their religious identities were shown to be authentic through the 'living out' of their beliefs, both in terms of the sharing of their faith with other believers, but also activities such as volunteering and helping others in a wider sense. The enactment of belief therefore took place across a range of religious and secular spaces, often outside of traditional church contexts, hence de-constructing and re-interpreting 'the sacred'. Spaces such as the pub and the street were therefore highlighted as significant for young people's performance of contemporary Christianity.

Religious practice is of course intensely corporeal, often involving ritual actions that "performatively produce and transform bodies and identities" (Vincett et al. 2012: 278). The ritualised expression of religion is something that is often learnt and experienced at quite a young age, as documented by Ridgely's (2005) work on children's interpretation of First Communion. As the primary ritual of the Catholic Church's seven sacraments, and the second of the three initiation rites, participation in the Eucharist represents an important step towards full membership of the congregation. As such, the seven and eight year olds in Ridgely's (2005) study approached the event with a very strong sense of anticipation, but for rather different reasons than the adults involved. The children's focus was on the embodied actions involved 
with the ritual - the eating, drinking and tasting of the bread and wine - rather than the beliefs associated with these actions. This was not because they did not understand the beliefs (all had attended numerous preparatory classes), but rather they desired to be properly included in the church community through active participation in its central ritual. In other words, the embodied performance of the religious ritual helped to constitute the children's developing identities as young Catholics.

Embodied geographies can also be significant for the development of religious-based institutional identities, as was the case in Hemming's (2015) research on religion in the primary school. Whilst a variety of rituals were used to build a sense of community and togetherness in the Catholic school featured in the study, children nevertheless demonstrated their ability to negotiate these requirements through embodied acts of resistance, such as subtly avoiding to take part in collective class prayers, or (in the case of Muslim pupils) changing the words of the prayers in their heads. Religious agency was also evident in the alternative understandings of school assemblies that children in the study expressed compared with adults. Whilst such events were designed for pupils to develop morally and spiritually, children's accounts often focused on the intensely embodied sensations of soreness and stiffness caused by sitting on a wooden floor in the school hall for an extended period of time, along with feelings of enjoyment experienced when performing bodily actions to hymns and songs. These findings concur with those of Scourfield et al. (2013) explored earlier, where children also used embodied practices to subtly contest religious socialisation.

\section{Belonging}

The previous section began to touch on issues of community and belonging, an important area of study in social and cultural geography, and this theme is explored further here. The potential of religious communities to act as a source of belonging for children and young people is illustrated well in research by Sharma and Guest (2013) on Christian students' experiences at English universities. Moving away from home for the first time can be a quite a stressful event for many young people, and the authors highlight how seeking membership of new Christian collectives can help to alleviate feelings of isolation. However, mobility between one Christian community at home and another at university often had quite significant impacts on participants' religious identities. The university contexts typically provided young people with the opportunity to reaffirm and/or renegotiate their religious beliefs and identities, sometimes influenced by new intra-generational peer relationships, or alternatively to re-evaluate their faith altogether as a result of academic or social experiences. Going away to university therefore had the potential to both reinforce and challenge young people's religious identities.

The existence of close-knit religious communities does not necessarily imply that everyone always feels like they belong. Indeed, it is now well established in social scientific thought that the ideal of community can actually result in exclusion, when the promotion of homogeneity and unity over difference and diversity means that certain individuals find they do not 'fit in'. In Sharma and Guest's (2013) research, a number of the young people recounted negative experiences of feeling excluded from Christian groups they had attended at university, inevitably presenting challenges for their religious identities. The participants gave a number of potential reasons for these feelings of alienation, including divergent personalities and interests, but also ethnic and social class differences. Similarly, a lack of belonging in the context of religious communities was experienced by some of the young Christians in Hopkins et al.'s (2011) study, particularly in cases where religious affiliations had changed, often leading to intergenerational conflict.

The two studies above refer primarily to those young people who actively engage with religion and for whom their Christian identity and beliefs are very important. However, Christian affiliation can also relate to much wider patterns of belonging, as illustrated by Day's (2011) research on belief and social identity in the modern world. Many of the young people in her study identified strongly with the 'Christian' label yet admitted a lack of religiosity or Christian 
belief and practice. This was because they viewed the label as an ascribed identity that denoted membership and belonging of other collectives, most notably their extended family unit and friendship networks, but also a wider ethno-cultural 'English' identity of which Christianity was viewed as integral. The term 'Christian' therefore acted as a marker of difference that differentiated interviewees from certain religious and ethnic 'others', such as Asians and Muslims. Day (2011) refers to this tendency as 'Christian nominalism', emphasising its performative qualities and its significance for understanding the dynamics of belonging.

The issue of belonging is particularly pertinent for minority religious groups in a multi-faith context and is often influenced by religious citizenship and inter-faith relations. These processes often relate to much more 'official' and 'institutional' understandings of belonging than those explored above. Hemming (2015) defines the concept of 'religious citizenship as the role of religion in devising criteria for access to state or community membership, the political rights and responsibilities attributed to particular religious groups within that membership, and the religious aspects of collective social/cultural identity that influence belonging. The concept builds on theories of multicultural citizenship (e.g. Joppke, 2007; Kymlicka, 2007), hence recognising the close but complex relationship between religion and ethnicity evidenced in the work of Day (2011) discussed above. For children and young people, religious citizenship and inter-faith relations are most likely to affect them at the level of the school and the local neighbourhood. These contexts are therefore the focus of the remainder of this section.

In the school context, religious citizenship is often partly constituted through the recognitions and accommodations extended to children from minority faith groups, inevitably impacting upon their sense of belonging. These issues are explored by Hemming (2015) in the context of two contrasting primary schools, including the marking of festivals such as Eid and Diwali, coverage of world religions in religious education, the provision of prayer space and specific food needs, withdrawal from particular religious ceremonies and practices, and policies on minority religious dress. Although both schools in the study had made some progress towards catering for minority groups, decisions were highly contested by school stakeholders and often intermeshed with wider issues about school and community identity. As Nesbitt (2004) shows in her ethnographic work on religious education, such arrangements are also significant for religious identity. Children construct and negotiate their developing identities in the context of school practices and discourses, as a key influence in secondary socialisation.

As discussed earlier, identities are intensely relational, pointing to the significance of interreligious dynamics for processes of belonging. Hemming (2015) found that primary school practices were important for the fostering of positive relations between pupils of different faiths, through the teaching of 'emotion work' and other embodied forms of social cohesion. Keddie (2014) similarly recognised the importance of school ethos for harmonious inter-faith relations in the secondary school context, but emphasised how the socially contingent nature of pupil's own understandings of religious identity could also contribute to a cohesive school community. Schools cannot be viewed in isolation from their local neighbourhoods and a number of studies, including those by Ipgrave (2012) and Holden (2009) have highlighted the importance of locality and region for understanding pupil attitudes towards religion and religious difference. According to this research, the quality of inter-religious relations in schools and the extent to which they can be considered as socially cohesive is significantly influenced by neighbourhood factors such as levels of religiosity, ethnic and religious diversity and local political discourses.

\section{Conclusion}

In mapping the field of scholarly work on childhood, youth and religion, the significance of geography is difficult to ignore, and references to geographical concepts and perspectives have been made throughout the chapter. Taken as a whole, there are six aspects that have emerged in particular, but these should by no means be viewed as exhaustive. They include the following: 
- One of the most important religious 'spaces' is a metaphorical one - the space of intergenerational socialisation and transmission. The research discussed has shown this space to be much more complex than often assumed, involving active participation from adults and children, and resulting in multiple positions and multi-directional processes.

- Whilst religion is most frequently associated with sacred sites and spaces, a whole range of diverse 'alternative' or 'secular' sites of enactment and transmission are evident in the research literature. They include youth groups, car journeys, pubs, country walks and cyberspace.

- Embodied geographies were central to the performance of religion, challenging the rigid distinction between belief and ritual or practice. Somatic experiences and actions were also integral to expressions of religious agency, such as subtle contestations of practice, and child-centred religious perspectives, such as sensual and embodied experiences.

- Mobilities emerged as important, particularly in terms of their potential to contribute to changes in religious identity. This was shown in the context of international migration and the 'generation effect' (Madge et al. 2014) as well as more local examples of mobility, such as the experience of moving to university.

- The contested nature of community and its links with religious identity have featured heavily in the chapter, whether understood as a small religious group or community, a school institutional community, a diasporic community, or a wider national and ethnocultural community.

- Place and locality, the most fundamental of geographical concepts, have also proved important for influencing individual religious beliefs and school-based inter-faith relations, something that Madge et al. (2014) refer to as 'locality ethos'. Place does not determine children's and young people's identities, but it certainly plays a role in contributing to its ongoing development.

Despite the importance of geography for making sense of the research literature in this field, there still remains a lack of systematic engagement with issues of religion within geographies of childhood and youth. Much of the explicitly geographical work to date appears to sit more comfortably within the geographies of religion sub-discipline than children's geographies. The two fields would certainly benefit from a more sustained dialogue and an acceptance from the sometimes rather secular academy that religion is indeed an important aspect of many children's and young people's everyday lives and as such deserves the attention that other areas of social identity have already received. Geographies of childhood and youth have much to offer this field, particularly methodologically and theoretically, such as expertise with childcentred methods and insights into the significance of space and place.

Viewed as a whole, the field of research on childhood, youth and religious identity would benefit from more attention to early and middle childhoods, rather than just young people and adolescents. There is also much potential to widen the scope of study to a more diverse range of religious identities, to encompass both mainstream and more peripheral religious and spiritual traditions, thus correcting the current dominance of work on Christianity and Islam. This should almost certainly include a consideration of non-religious positions such as atheism, humanism and secularism, which are becoming more important in the wider field of religious studies and the sociology of religion. Finally, a more thorough engagement with the multiple sites and spaces of children and young people's religious lives that have begun to emerge from the existing work in this area would help to further enrich the field. Geography is integral to this research agenda and hence it is imperative that geographers play an active role in its development and realisation.

\section{References}


Barker, J. and Weller, S. (2003) "Is it fun?" Developing children centred research methods. International Journal of Sociology and Social Policy, 23(1/2): 33-58.

Baumann, G. (1996). Contesting Culture: Discourses of Identity in Multi-Ethnic London. Cambridge: Cambridge University Press.

Boyatzis, C.J., Dollahite, D.C. and Marks, L.D. (2006). The family as a context for religious and spiritual development in children and youth. In E. Roehlkepartain, P. Ebstyne King, L. Wagner and P.L. Benson (Eds.), The Handbook of Spiritual Development in Children and Youth (pp.297-309). London: Sage.

Bradley, H. (1996). Fractured Identities: Changing Patterns of Inequality. Cambridge: Polity Press.

Bunge, M.J. (2006). The child, religion, and the academy: developing robust theological and religious understandings of children and childhood. Journal of Religion, 86(4), 549-579.

Coles, R. (1990). The Spiritual Life of Children. Boston: Houghton Mifflin.

Day. A. (2011). Believing in Belonging: Belief and Social Identity in the Modern World. Oxford: Oxford University Press.

Davie, G. (2007) The Sociology of Religion. London: Sage.

Duderija, A. (2007). Literature review: identity construction in the context of being a minority immigrant religion: the case of Western-born Muslims. Immigrants and Minorities, 25(2), 141162.

Dwyer, C. (1998). Contested identities: challenging dominant representations of young British Muslim women. In T. Skelton and G. Valentine (Eds.), Cool Places: Geographies of Youth Cultures (pp.50-65). London: Routledge.

Dwyer, C. (1999). Veiled meanings: Young British Muslim women and the negotiation of differences. Gender, Place and Culture, 6(1), 5-26.

Erricker, C., Erricker, J. Ota, C., Sullivan, D. and Fletcher, M. (1997). The Education of the Whole Child. London: Cassell.

Francis, L.J. (2001). The Values Debate: A Voice from the Pupils. London: Woburn Press.

Giddens, A. (1991) Modernity and Self Identity. Cambridge: Polity.

Goldman, R. (1964). Religious Thinking from Childhood to Adolescence. London: Routledge and Kegan Paul.

Hall, S. (1992). The question of cultural identity. In S. Hall, D. Held and T. McGrew (Eds.), Modernity and its Futures: Understanding Modern Societies (pp.273-326). London: Sage.

Hart, T. (2003). The Secret Spiritual World of Children. Makawao: Inner Ocean.

Hay, D. and Nye, R. (1998). The Spirit of the Child. London: HarperCollins.

Heller, D. (1986). The Children's God. Chicago: University of Chicago Press.

Hemming, P.J. (2015). Religion in the Primary School: Ethos, Diversity, Citizenship. London: Routledge. 
Hemming, P.J. and Madge, N. (2012). Researching children, youth and religion: identity, complexity and agency. Childhood, 19(1), 38-51.

Holden, A. (2009). Religious Cohesion in Times of Conflict: Christian-Muslim Relations in Segregated Towns. London: Continuum.

Honig, M-S. (2009). How is the child constituted in childhood studies?. In J. Qvortrup, W.A. Corsaro and M-S Honig (Eds.), The Palgrave Handbook of Childhood Studies (pp.62-77). Basingstoke: Palgrave MacMillan.

Hopkins, P. (2004). Young Muslim men in Scotland: inclusions and exclusions. Children's Geographies, 2(2), 257-272.

Hopkins, P., Olsen, E., Pain, R. and Giselle, V. (2011). Mapping intergenerationalities: the formation of youthful religiosities. Transactions of the Institute of British Geographers, 36(2), 314-327.

Ipgrave, J. (2012). Relationships between local patterns of religious practice and young people's attitudes to the religiosity of their peers. Journal of Beliefs and Values, 33(3), 261-274.

Jackson, R. (1997) Religious Education: An Interpretive Approach. London: Hodder and Stoughton.

Jackson, R. (2004) Rethinking Religious Education and Plurality: Issues in Diversity and Pedagogy. London: RoutledgeFalmer.

Jacobson, J. (1998). Islam in Transition: Religion and Identity among British Pakistani Youth. London: Routledge.

James, A. (2001). Ethnography in the study of childhood. In P. Atkinson, A. Coffey, S. Delamont, J. Lofland and L. Lofland (Eds.), Handbook of Ethnography (pp.246-257). London: Sage.

James, A., Jenks, C. and Prout, A. (1998). Theorizing Childhood. Cambridge: Polity. Joppke, C. (2007). Transformation of citizenship: status, rights, identity. Citizenship Studies 11(1), 37-48.

Kay, W.K. and Francis, L.J. (1996). Drift from the Churches: Attitude toward Christianity during Childhood and Adolescence. Cardiff: University of Wales Press.

Keddie, A. (2014). Students' understandings of religious identities and relations: issues of social cohesion and citizenship. Education, Citizenship and Social Justice, 9(1), 81-93.

Kong, L. (1990). Geography and religion: trends and prospects. Progress in Human Geography, 14(3), 355-371.

Kong, L. (2001). Mapping 'new' geographies of religion: politics and poetics in modernity. Progress in Human Geography, 25(2): 211-233.

Kong, L. (2010). Global shift, theoretical shifts: changing geographies of religion. Progress in Human Geography, 34(6), 755-776.

Kymlicka, W. (2007). Multicultural Odysseys: Navigating the New International Politics of Diversity. Oxford: Oxford University Press. 
Levitt, M. (2003). Where are the men and boys? The gender imbalance in the Church of England. Journal of Contemporary Religion, 18(1), 61-75.

Lewis, P. (2007). Young, British and Muslim. London: Continuum.

Lincoln, B. (2006). Holy Terrors: Thinking about Religion after September 11 (2 ${ }^{\text {nd }}$ ed.). Chicago: University of Chicago Press.

Madge, N., Hemming, P.J. and Stenson, K. (2014). Youth on Religion: The Development, Negotiation and Impact of Faith and Non-Faith Identity. London: Routledge.

Mason, M., Singleton, A. and Webber, R. (2007). The Spirit of Generation Y: Young People's Spirituality in a Changing Australia. Mulgrave: John Garratt.

McKenna, U., Ipgrave, J. and Jackson R. (2008). Interfaith Dialogue by Email in Primary Schools: An Evaluation of the Building E-Bridges Project. Münster: Waxmann.

Miller-McLemore, B. (2006). Whither the children? Childhood in Religious Education'. Journal of of Religion, 86(4), 635-657.

Moinian, F. (2009). "I'm just me!" Children talking beyond ethnic and religious boundaries.

Childhood, 16(1), 31-48.

Musolf, G.R. (1996). Interactionism and the child: Cahill, Corsaro and Denzin on childhood socialization. Symbolic Interactionism, 19(4), 303-321.

Nesbitt, E. (2004). Intercultural Education: Ethnographic and Religious Approaches. Brighton: Sussex Academic Press.

Payne, G. (2000). An introduction to social divisions. In G. Payne (Ed.), Social Division (pp.119). London: Sage.

Prout, A. and James, A. (1997). A new paradigm for the sociology of childhood? Provenance, promise and problems. In A. James and A. Prout (Eds.), Constructing and Reconstructing Childhood: Contemporary Issues in the Sociological Study of Childhood (pp.7-32). London: Falmer.

Raj, D.S. (2000)."Who the hell do you think you are?" Promoting religious identity among young Hindus in Britain. Ethnic and Racial Studies, 23(3), 535-558.

Ramji, H. (2007). Dynamics of religion and gender amongst young British Muslims. Sociology, 41(6): 1171-1189.

Ridgely, S.B. (2004). When I Was a Child: Children's Interpretations of First Communion. Chapel Hill: University of North Carolina Press.

Ridgley, S. (2012). Children and Religion. Religious Compass, 6(4), 236-248.

Scourfield, J., Gilliat-Ray, S., Khan, A. and Otri, S. (2013). Muslim Childhood: Religious Nurture in a European Context. Oxford: Oxford University Press.

Sharma, S. and Guest, M. (2013). Navigating religion between university and home: Christian students' experiences in English universities. Social and Cultural Geography, 14(1), 59-79.

Smith, C. and Denton, M.L. (2005). Soul Searching: The Religious and Spiritual Lives of American Teenagers. Oxford: Oxford University Press. 
Smith, C., Faris, R., Denton, M.L. and Regenerus, M. (2003). Mapping American adolescent subjective religiosity and attitudes of alienation toward religion: a research report. Sociology of Religion, 64(1), 111-133.

Stark, R. and Glock, C.Y. (1968) American Piety: The Nature of Religious Commitment. Berkley, CA: University of California Press.

Valentine, G. and Sporton, D. (2009). How other people see you, it's like nothing that's inside: the impact of processes of disidentification and disavowel on young people's subjectivities.

Sociology, 43(4), 735-751.

Vincett, G., Olson, E., Hopkins, P. and Pain, R. (2012). Young people and performance Christianity in Scotland. Journal of Contemporary Religion, 27(2), 275-290.

Yip, A.K.T. and Page, S.-J. (2013). Religious and Sexual Identities: A Multi-Faith Exploration of Young Adults. Aldershot: Ashgate.

Wallace, J.M.J., Forman, T.A., Caldwell, C.H. and Willis, D.S. (2003). Religion and US secondary school students: current patterns, recent trends and sociodemographic correlates. Youth and Society, 35(1), 98-125.

Ziebertz, H-G. and Kay, W. (2006). (Eds.) Youth in Europe II: An International Empirical Study About Religiosity. Berlin: LIT-Verlag.

\section{Keywords}

religion, religious, identity, agency, socialisation, belief 